Nig. J. Biotech. Vol. 38 (2) : 56-66 (Dec 2021)

ISSN: 01891731

Available online at

http://www.ajol.info/index.php/njb/index

and $w$ ww.biotechsocietynigeria.org

DOI: https://dx.doi.org/10.4314/njb.v38i2.6

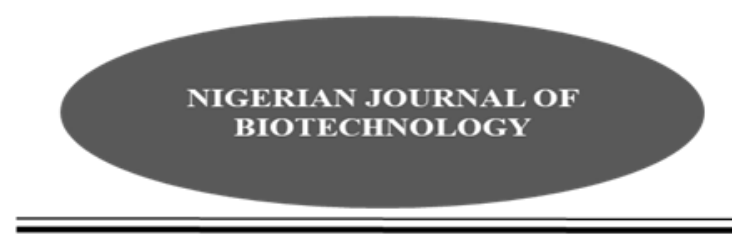

\title{
Characterization of Novel Alkaline Protease producing Bacillus subtilis C3a-FIIRO with Potential for Industrial Application
}

\author{
${ }^{1}$ Fashola, F.A., ${ }^{1}$ Fadipe, O.T., ${ }^{1}$ Nwagala, P.N., ${ }^{1}$ Olatope, S.O., ${ }^{1}$ Augustine, C.P., \\ ${ }^{1}$ Ibidapo, O.I., ${ }^{1}$ James, I. C., ${ }^{1}$ Aderinwale, F.B., ${ }^{1}$ Orji, F.A. and ${ }^{1}$ Lawal, A.K. \\ ${ }^{1}$ Biotechnology Department, Federal Institute of Industrial Research Oshodi, Lagos, Nigeria.
}

\begin{abstract}
Microbial alkaline protease is one of the dominant industrial enzymes which function in splitting polypeptides chain of protein into monomers of amino acids and peptides. This study aimed to identify alkaline protease produced by Bacillus sp. Soil samples were aseptically collected from dump sites in FIIRO, Lagos state, Nigeria. The samples were serially diluted, and bacteria were isolated using pour plate method. The resulting isolates were screened and morphologically characterized. The isolate with the highest protease production potential was subjected to biochemical characterization using Analytical Profile Index (API) identification kit system and 16S rRNA sequencing. The selected isolate was used to produce alkaline protease by solid state fermentation using rice bran as a substrate. Out of the 18 bacteria isolated, 11 isolates showed alkaline protease production potential. Isolate C3a-FIIRO was selected for its maximal alkaline protease produced as indicated by a $56 \mathrm{~mm}$ zone of clearance. Morphological and biochemical characterization revealed isolate C3a-FIIRO as a member of the genus Bacillus. The 16S rRNA gene sequencing confirmed the isolate as Bacillus subtilis C3aFIIRO (MW577298) with closest homology to Bacillus subtilis Y17B. The enzyme activity of $6848.171 \mathrm{U} / \mathrm{ml} \pm 0.11$ and protein concentration of $152.13 \mathrm{mg} / \mathrm{ml} \pm 0.003$ showed that Bacillus subtilis C3a-FIIRO has potential for sustainable alkaline protease production.
\end{abstract}

Keywords: Bacillus sp, Alkaline protease, Hyperproducer, 16S rRNA gene sequencing

Corresponding author: flakkylady@gmail.com

\section{Introduction}

The dependency of the nation on importation of industrial enzymes implies there is no industry currently producing these enzymes in Nigeria, which positions the nation continuously on the radar of other importing nations with strong prospect for these enzymes. Protease is one of such industrial enzymes which function in hydrolytic catalysis of proteins to peptides and amino acids (Sharma et al., 2019). Based on pH, they are classified as acidic, alkaline, and neutral proteases (Ellaiah et al., 2002; Sayaniya \& Patel, 2021). Among these three proteases, alkaline protease (EC 3.4.21), which are active at alkaline $\mathrm{pH}$, occupy a pivotal position due to their wide industrial application in food, brewing, dairy, and pharmaceutical industries (Kumar et al., 1999; Varia et al., 2019; Manavalan et al., 2020).

Microorganisms have been considered important sources of protease due to their potential for producing alkaline protease in large quantities within a short period of time by established fermentation methods (Gupta et al., 2002; Sharma et al., 2019, Varia et al., 2019). Microbial alkaline protease also occupies a major share of $60 \%$ of the total enzyme market from industrial point of view (Gupta et al., 2002; Razzaq et al., 2019). The ability of microbes to meet global enzyme demand has led to an increased interest compared to plants and animals (Kumar et al., 
2008). This interest stems from the safe technology, efficient resource utilization, its contribution to reduced carbon emission (Oxenbøll \& Ernst, 2008), and no ethical issues which is usually a concern with animal systems (Dalvi \& Anthappan, 2007; Imen et al., 2016).

Among the alkaline protease producing microorganisms, members of the Bacillus genus are considered the best producers of most commercially available proteases (Ellaiah et al., 2002; Shafee et al., 2005; Cheng et al., 2012; Zhou et al., 2019; Karray et al., 2021). Bacillus species have been identified as important industrial microorganisms due to their rapid growth rate, extracellular secretion of enzyme and generally recognized as safe status thus making them bacterial workhorses in industrial microbial cultivations to produce a variety of enzymes (Pandey et al., 2000; Gouda et al., 2006; Vijayalakshmi et al., 2012; Deb et al., 2013; Karray et al., 2021).

The benefit of exploiting microorganisms for industrial applications and the need to encourage biodiversity characterization makes the identification of these organisms important. This is supported by the advantages offered using molecular biology techniques to confirm identity, thus improving the characterization of microorganisms (Keramas et al., 2004; Magistrado et al., 2001; Frederick et al., 2013). With the rising demand for protease enzymes in the industries and the industrial value of alkaline protease, the search for suitable microbial sources is of continuous interest. Thus, this study focuses on identifying a novel bacterial strain isolated from the soil with hyper alkaline protease producing potential.

\section{Material and Methods}

\section{Isolation and Screening for Alkaline Protease Production}

Soil samples were collected from FIIRO dump sites (canteen effluent and general waste sites) aseptically. Isolation was conducted by the method described by Lawal et al. (2014). Ten grams of soil samples was measured and suspended in $90 \mathrm{ml}$ of sterile distilled water. The resulting suspension was subjected to serial dilution up to $10^{-8}$ under aseptic conditions. The isolation medium was sterilized in an autoclave at $121^{\circ} \mathrm{C}$ for $15 \mathrm{~min}$. After cooling, the sample from each dilution $(0.1 \mathrm{ml})$ was dispensed by pour plating into the nutrient agar medium and incubated at $37^{\circ} \mathrm{C}$ for $24 \mathrm{~h}$. The Isolates were subcultured to purity by streak plate technique and preserved on Luria Bertani (Oxoid, Basingstoke, U.K.) slant at $4{ }^{\circ} \mathrm{C}$. The purified isolates were further subjected to screening for alkaline protease production by plate assay using nutrient agar screening medium containing casein ( $2 \%)$ as the sole substrate. The purified isolates were plated into freshly prepared nutrient agar plates and incubated at $37^{\circ} \mathrm{C}$ for $24 \mathrm{~h}$. After $24 \mathrm{~h}$, the plates were flooded with dilute mercury chloride (Merck, Germany) as a protein precipitating agent, to observe and measure the zone of hydrolysis around colonies as described by the method of Balan et al. (2012). The percentage hydrolysis efficiency was determined by the method described by Sreedevi and Reedy (2012). The maximal hyper alkaline protease producer was selected for further investigations.

\section{Characterization of Selected Isolates}

Morphological and biochemical characteristics of pure isolates of the protease producers were determined as described in Bergey's manual of systematic bacteriology (Claus \& Berkeley, 1986). The selected hyper alkaline protease producer, isolate C3a-FIIRO, was further identified using API 50CHB/20E (Biomerieux, France). Pure colonies of the isolate grown on nutrient agar were suspended in saline solution and used as inoculum for API $50 \mathrm{CHB} / 20 \mathrm{E}$ tests according to the manufacturer's instruction. The inoculated medium was incubated at $36^{\circ} \mathrm{C}$ for $24-48 \mathrm{~h}$ and results were recorded and interpreted using the API web database system (Aruwa \& Olatope, 2015).

\section{Molecular Characterization of Isolate C3a-FIIRO}

Genomic DNA was extracted from bacterial broth incubated for $16-18 \mathrm{~h}$ at $37^{\circ} \mathrm{C}$ and $150 \mathrm{rpm}$ using Quick-DNA Fungal/Bacterial kit (Zymo Research) with slight modifications to the manufacturer's protocol. The purity and quantity of DNA were determined using the ThermoScientific Nanodrop 2000c. Extracted DNA 
Fashola et al. / Nig. J. Biotech. Vol. 38 Num. 2 : 56-66 (December 2021)

was further resolved on $1 \%$ agarose in $1 \mathrm{x}$ TAE buffer. The $16 \mathrm{~S}$ rRNA hypervariable region in the extracted genomic DNA was amplified using 27F - AGAGTTTGATCMTGGCTCAG and 1492R CGGTTACCTTGTTACGACTT primers in a $50 \mu \mathrm{l}$ $P C R$ reaction mixture. The mixture contained 10 $\mu \mathrm{l}$ of Solis BioDyne 5x FIREPol ${ }^{R}$ Master Mix Ready to Load $\left(12.5 \mathrm{mM} \mathrm{MgCl}_{2}\right), 22.5 \mu$ nuclease free water, $2.5 \mu \mathrm{l}$ of $10 \mu \mathrm{M}$ forward and reverse primers, $12.5 \mu \mathrm{l}$ DNA. Cycling conditions consisted of: initial denaturation at $95{ }^{\circ} \mathrm{C}$ for 5 min, denaturation at $95^{\circ} \mathrm{C}$ for 30 secs, annealing temperatures at $49.5^{\circ} \mathrm{C}$ for 1 min, extension at $72{ }^{\circ} \mathrm{C}$ for $2 \mathrm{~min}$, final extension at $72{ }^{\circ} \mathrm{C}$ for 10 min and hold at $4{ }^{\circ} \mathrm{C}$ in a Cleaver Scientific GTC96S thermal cycler. Amplicons were resolved on $2 \%$ agarose in $1 x$ TAE and the gel was documented. The $>1.5 \mathrm{~kb}$ PCR amplicon was sequenced at Inqaba Biotec (South Africa). The sequences were trimmed and edited using Sequencher version 5.4.6. Sequence homology was done using NCBI-BLAST and alignment using ClustalW in MEGA 7. Phylogenetic analysis was done using the Jukes-Cantor algorithm of the Neighbor-Joining method considering 1000 bootstrap replications in MEGA 7 with Pseudomonas sp B3044 (JX266400.1) as an outgroup.

\section{Production of Alkaline Protease}

Fifty millilitres of growth medium containing $0.8 \%$ nutrient broth (peptone, $0.3 \%$; yeast extract, $0.4 \%$ ) was prepared in a $250 \mathrm{ml}$ Erlenmeyer flask. The prepared medium was inoculated aseptically with a loopful of purified isolate C3a-FIIRO. The inoculated medium was transferred to a shaking incubator set at $37^{\circ} \mathrm{C}$ for $24 \mathrm{~h}$ as described by the method of Lawal et al. (2014). Solid state fermentation for alkaline protease production was performed using ricebran as substrate. The rice bran $(10 \mathrm{~g})$ was sterilized for $1 \mathrm{~h}$ at $121^{\circ} \mathrm{C}$ to eliminate microbial contamination, while the production medium was sterilized for $15 \mathrm{~min}$ at $121^{\circ} \mathrm{C}$. The sterilized rice bran was moistened with $10 \mathrm{ml}$ of sterile production medium ( $\mathrm{pH} \mathrm{10)}$ which contained in $\mathrm{g} / \mathrm{l}, \mathrm{KH}_{2} \mathrm{PO}_{4}, 7.0 \mathrm{~g} ; \mathrm{MgSO}_{4}, 0.5 \mathrm{~g}$; $\left(\mathrm{NH}_{4}\right)_{2} \mathrm{SO}_{4}, 1 \mathrm{~g}$; Yeast extract, $5.5 \mathrm{~g} ; \mathrm{Na}_{2} \mathrm{CO}_{3}, 10 \mathrm{~g}$ and glucose, 1 $\mathrm{g}$. The moistened substrate was inoculated and incubated at $37^{\circ} \mathrm{C}$ for $96 \mathrm{~h}$ as described by the method of Lawal et al. (2014).

\section{Alkaline Protease Assay}

The assay followed the method described by Lawal et al. (2014) with some modifications. One millilitre of enzyme sample was diluted with $1 \mathrm{ml}$ of $0.2 \mathrm{M}$ borate buffer $(\mathrm{pH} \mathrm{10})$ containing $1 \mathrm{ml}$ casein. After incubation at $40^{\circ} \mathrm{C}$ for $10 \mathrm{~min}, 5 \mathrm{ml}$ of $5 \%$ trichloroacetic acid was added, and the resultant mixture was filtered using Whatman No.1 filter paper to remove precipitated proteins. Five millilitres of $0.5 \mathrm{M}$ sodium carbonate and 1 $\mathrm{ml}$ Folin phenol reagent was added to the filtrate sequentially. The resulting solution was inverted and allowed to stand at room temperature for 30 $\mathrm{min}$. The tyrosine equivalent released was measured using a spectrophotometer (VWR, United States) at the wavelength of $600 \mathrm{~nm}$. Standard tyrosine prepared in a series of concentrations $(50 \mu \mathrm{g} / \mathrm{ml}-500 \mu \mathrm{g} / \mathrm{ml})$ was also subjected to the same treatment as the test sample. One unit enzyme activity was defined as the amount of enzyme that released $1 \mu \mathrm{g}$ of tyrosine per $\mathrm{ml}$ per min under the above assay conditions.

\section{Protein Concentration Determination}

The protocol for protein content determination followed the method described by Lawal et al. (2014). Crude enzyme extract ( $0.2 \mathrm{ml}$ ) was added to tubes containing $0.8 \mathrm{ml}$ distilled water, inverted, and allowed to stand at room temperature for $10 \mathrm{~min}$. Folin phenol reagent $(0.5$ $\mathrm{ml}$ ) was added to the mixture, inverted, and left to stand at room temperature for $30 \mathrm{~min}$. The protein concentration was measured spectrophotometrically at $600 \mathrm{~nm}$. Standard bovine serum albumin $(10 \mathrm{mg} / \mathrm{ml})$ was also subjected to the same treatment as the test sample.

\section{Results and Discussions}

\section{Selection of hyper alkaline protease producer}

The selection and identification of industrially suitable organisms are very crucial to the production of alkaline protease. Among 18 colonially distinct isolates, 11 isolates demonstrated alkaline protease production potential, as shown in Table 1. 
Fashola et al. / Nig. J. Biotech. Vol. 38 Num. 2 : 56-66 (December 2021)

Table 1: Zone of hydrolysis of alkaline protease producing isolates

\begin{tabular}{lll}
$\mathbf{S} / \mathbf{N}$ & Isolate codes & Zone of clearance $(\mathbf{m m})$ \\
\hline $\mathbf{1}$ & C1-FIIRO & 11 \\
$\mathbf{2}$ & C3a-FIIRO & 56 \\
$\mathbf{3}$ & C7-FIIRO & 15 \\
$\mathbf{4}$ & C8-FIIRO & 14 \\
$\mathbf{5}$ & C11-FIIRO & 13 \\
$\mathbf{6}$ & D12-FIIRO & 53 \\
$\mathbf{7}$ & D13-FIIRO & 39 \\
$\mathbf{8}$ & D14-FIIRO & 18 \\
$\mathbf{9}$ & D15-FIIRO & 33 \\
$\mathbf{1 0}$ & D16-FIIRO & 34 \\
$\mathbf{1 1}$ & D17-FIIRO & 10 \\
\hline
\end{tabular}

C* indicates isolates obtained from soil sample collected from FIIRO canteen effluent dump site; D* indicates isolates obtained from soil sample collected from FIIRO's general waste dump site

Out of these isolates, C3a-FIIRO showed the best potential for alkaline protease production. The preference and selection of isolate C3a-FIIRO was due to visual evaluation of the zone of hydrolysis and its higher hydrolysis efficiency of 7.69 compared to isolate D12-FIIRO which was 1.92. There has been increased interest in the catalytic efficiency of microorganisms intended for protease enzyme production (Singh et al., 1999; Shumi et al., 2004; Khan et al., 2011). Based on the results, hydrolysis efficiency showed the ability of the alkaline producer to efficiently utilize substrates. It also shows that the secretion of the enzyme into the medium was growth associated.

Morphological Identification of Alkaline Protease Producing Isolates

Morphological studies revealed that all alkaline protease producing isolates possess different phenotypic characteristics, as shown in Table 2. They are also positive for catalase, oxidase and motility. Based on microscopic observation, isolate C3a- FIIRO was a Gram-positive, rodshaped, and spore-forming bacteria. As a result of potential phenotypic similarities between strains and the importance to maintain appropriate identification conditions, this method is not sufficient to classify the isolate as Bacillus $s p$. Thus, biochemical characterization using API identification system was employed as it has been shown to give reliable results in identifying bacterial species (Logan \& Berkeley, 1984; Collin et al.,1991; Thompson et al.,1993).

Table 2: Colonial characteristics of alkaline protease producing isolates

\begin{tabular}{lllllll}
\hline $\mathbf{S / N}$ & $\begin{array}{l}\text { Isolate } \\
\text { Code }\end{array}$ & Color/Opacity & Shape & Elevation & Margin & Texture \\
\hline $\mathbf{1}$ & C1-FIIRO & Cream & Circular & Flat & Entire & Non-slimy \\
$\mathbf{2}$ & C3a-FIIRO & Off white & Circular & Flat & Undulated & Non-slimy \\
$\mathbf{3}$ & C7-FIIRO & Off white & Circular (large) & Flat & Serrated & Non-Slimy \\
$\mathbf{4}$ & C8-FIIRO & Cream & Punctiform & Flat & Entire & Non-slimy \\
$\mathbf{5}$ & C11-FIIRO & Cream & Circular & Flat & Entire & Non-slimy \\
$\mathbf{6}$ & D12-FIIRO & Off white & Circular & Raised & Serrated & Slimy
\end{tabular}


Fashola et al. / Nig. J. Biotech. Vol. 38 Num. 2 : 56-66 (December 2021)

\begin{tabular}{lllllll}
$\mathbf{7}$ & D13-FIIRO & Off white & Irregular (hairy) & Flat & Filamentous & Non-slimy \\
$\mathbf{8}$ & D14-FIIRO & Off white & Circular & Flat & Serrated & Non-slimy \\
$\mathbf{9}$ & D15-FIIRO & Off white & Circular (large) & Raised & Serrated & Non-slimy \\
$\mathbf{1 0}$ & D16-FIIRO & Off white & Circular & Raised & Undulated & Slimy \\
$\mathbf{1 1}$ & D17-FIIRO & Off white & Irregular & Raised & Undulated & Slimy \\
\hline
\end{tabular}

C* indicates isolates obtained from soil sample collected from FIIRO canteen effluent dump site; D* indicate isolates obtained from soil sample collected from FIIRO's general waste dump site

\section{Biochemical Characterization of Isolate C3a- FIIRO}

Biochemical characterization of isolate C3a-FIIRO was done using the API identification system with API kits 50CHB and 20E (Biomerieux, France). Eight biochemical tests were omitted in API 20E because they were present in biochemical tests conducted using API 50CHB. This identification system is based on the ability of the organism to ferment various substrates during metabolism to generate byproducts that can be detected by various color changes. The evaluation of substrate fermentation potentials and enzyme activities of C3a FIIRO implies that it belongs to the Bacillus genus and certain biochemical characteristics have been associated with bacillus subtilis. The positive characteristic properties of

Table 3: Fermentation and biochemical profile for alkaline protease producing Bacillus sp C3a-FIIRO

\begin{tabular}{llllll} 
Tests & $24 \mathrm{~h}$ & $48 \mathrm{~h}$ & Tests & $24 \mathrm{~h}$ & $48 \mathrm{~h}$ \\
\hline Glycerol & + & + & D-saccharose & + & + \\
Erythritol & - & - & D-trehalose & + & + \\
D-arabinose & - & - & Inulin & + & + \\
L-arabinose & + & + & D-melezitose & - & - \\
D-ribose & + & + & D-raffinose & $+?$ & $+?$ \\
D-xylose & + & + & Starch & + & + \\
L-xylose & - & - & Glycogen & + & + \\
D-adonitol & - & - & Xylitol & + & - \\
Methyl-b-D- & & & Gentiobiose & + & + \\
Xylopyranoside & - & - & D-turanose & + & + \\
D-galactose & + & + & D-lyxose & + & + \\
D-glucose & + & + & D-tagatose & - & - \\
D-fructose & + & + & D-fucose & - & - \\
D-mannose & + & + & L-fucose & - & - \\
L-sorbose & - & - & D-arabitol & - & - \\
L-rhamnose & $+?$ & $+?$ & L-arabitol & $+?$ & $+?$ \\
Dulcitol & - & - & Potassium gluconate & - & - \\
Inositol & $+?$ & $+?$ & Potassium 2-ketogluconate & - & - \\
D-mannitol & + & + & Potassium 5-ketogluconate & - & + \\
D-sorbitol & + & + & Beta-galactosidase & + &
\end{tabular}

catalase, oxidase, Voges Proskauer test, nitrate reduction, citrate utilization, gelatinase activity, starch hydrolysis motility with the endospore formation and the negative result of indole, methyl red, urease and lactose as shown in Table 3, were indicative of bacillus subtilis. This biochemical profile was similar to other Bacillus subtilis strains isolated by Hussein et al. (2013), Demeli et al. (2014), Aruwa and Olatope (2015). In contrast, the three cellulolytic Bacillus subtilis strains isolated by Kim et al. (2012) showed slight differences from each other in biochemical properties as amygdalin, D-maltose, D-lactose, glycogen, inulin, methyl-a-D-glucopyranoside, salicin, gentiobiose and D-turanose utilization gave positive results in our study, while D-lactose utilization was not visible. 
Fashola et al. / Nig. J. Biotech. Vol. 38 Num. 2 : 56-66 (December 2021)

\begin{tabular}{llllr}
\hline Methyl-a-D- & & & $\begin{array}{l}\text { Arginine dihydrolase } \\
\text { Lysine decarboxylase }\end{array}$ \\
$\begin{array}{llll}\text { Mannopyranoside } \\
\text { Methyl-a-D- }\end{array}$ & - & - & & Ornithine decarboxylase \\
glucopyranoside & + & + & Trisodium citrate & - \\
N-acetylglucosamine & + & + & H2S (sodium thiosulfate) & + \\
Amygdalin & + & + & Urease & - \\
Arbutin & + & + & L-tryptophan & - \\
Esculin (ferric citrate) & + & + & Indole & + \\
Salicin & + & + & Voges Proskauer test & + \\
D-cellobiose & + & + & Gelatinase & + \\
D-maltose & + & + & Nitrate & + \\
D-lactose (bovine origin) & $+?$ & $+?$ & & \\
D-melibiose & $+?$ & $+?$ & &
\end{tabular}

key: + : positive reaction. $\quad$-: negative reaction: + ? sign indicate reaction not too visible

\section{Molecular Characterization of Isolate C3a-FIIRO}

Due to the heterogeneity of the Bacillus genus and the possibility of generating inconsistent results (Gordon et al., 1973; Logan \& Berkeley, 1984), further confirmation of the identity of isolate C3a-FIIRO was required. Molecular biology techniques were employed using $16 \mathrm{~S}$ rRNA sequencing, a common genetic marker that is considered a rapid and reliable technique in the identification of Bacillus sp (Goto et al., 2000; Frederick et al., 2013), because of its reproducibility and higher accuracy as reported by Bajpai et al. (2017) and Khusro and Aarti (2015). The purity (A260/280) of extracted genomic DNA from isolate C3a-FIIRO was within the expected range of 1.8 and 2.0 for good quality DNA. The expected amplicon size of $\geq 1.5$ $\mathrm{kb}$ for successful amplification of the 16S rRNA hypervariable region was observed in Figure 1.
The 16S rRNA nucleotide sequences of isolate C3a-FIIRO was 1459 bp long. Sequence homology on NCBI-BLAST revealed that isolate C3a-FIIRO belongs to the Bacillus genus sharing closest homology with Bacillus subtilis strain Y17B (isolated from soil in China) at $99.79 \%$; hence it was Bacillus subtilis C3a-FIIRO. Its 16S rRNA sequences has been submitted to the NCBIGenBank under the accession number MW577298.

The phylogenetic tree constructed by neighbor joining method shows that Bacillus subtilis strain C3a-FIIRO (blue) is associated with genus Bacillus and clustering perfectly with other Bacillus subtilis strains, including Bacillus subtilis strain Y17B as shown in Figure 2. 


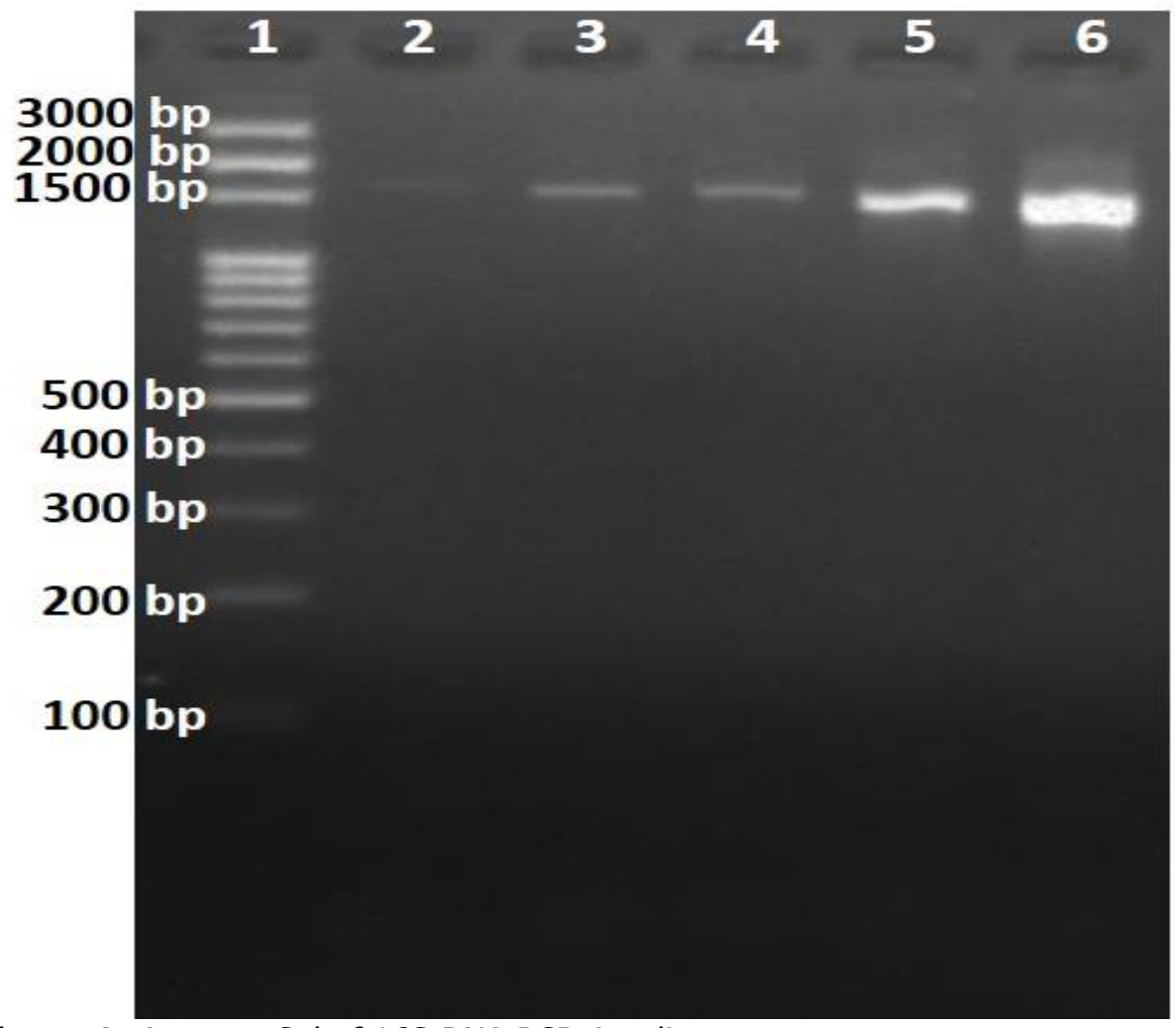

Figure 1: Agarose Gel of 16SrRNA PCR Amplicons

Lane 1 - 100 bp DNA Ladder, Lane 2 - dilution 1000, Lane 3 \& 4 - dilution 100, Lane 5 - dilution 10, Lane 6 - undiluted DNA.

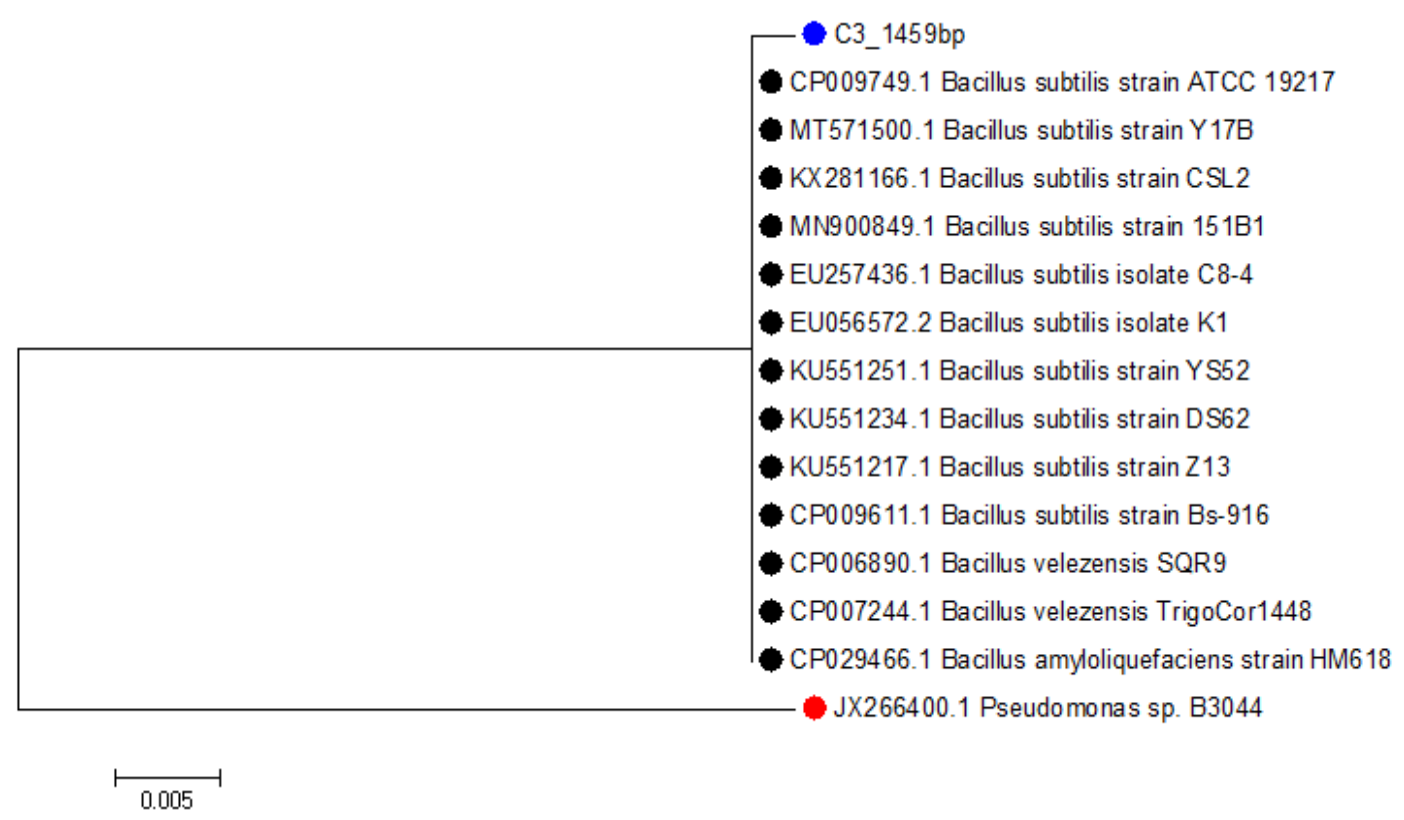

Figure 2: Phylogenetic Tree of Bacillus subtilis strain C3a-FIIRO 16SrRNA Nucleotide Sequences. The tree was constructed using the neighbor joining model with Pseudomonas sp B3044 (red) as an outgroup considering 1000 bootstrap replications in MEGA7. 
Due to the abundance of rice bran, an agro waste, in Nigeria and the need to reduce the contribution of agro wastes to environmental pollution, rice-bran was selected as a suitable substrate for solid state fermentation because of the stored nutrients (Faria et al., 2012). In order for microorganisms to grow, they must undergo metabolic processes that allow them to efficiently utilize nutrients for growth. Hence microbial enzymatic activity is a fundamental measure in nutrient utilization and the turnover from macromolecules to simpler monomers (Caruso et al., 2019). Upon exposure to certain inducers, different products of metabolic activities are secreted into the culture medium. In the presence of rice bran protein, it is believed that Bacillus subtilis C3a-FIIRO induced the secretion of alkaline protease as shown by the activity of $6848.171 \mathrm{U} / \mathrm{ml} \pm 0.11$ observed after 96 hours of fermentation and the protein concentration of $152.13 \mathrm{mg} / \mathrm{ml} \pm 0.003$. This activity displayed by isolate C3a FIIRO indicates the measure by which alkaline protease induced can catalyze the hydrolysis of the peptide bonds in the rice bran protein and generate peptides and amino acids that can then be utilized as a source of nutrients for microbial growth. In addition to the fermentation composition, the catalytic effect displayed by the produced alkaline protease is believed to be significantly influenced by the alkalinity of the production medium, suggesting the important role of $\mathrm{pH}$ in the production of the enzyme at the alkaline range.

As rice bran is a good source of proteins (Parekh et al., 2002; Naidu \& Devi, 2005; PaucarMenacho et al., 2007; Bhosale \& Vijayalakshmi, 2015), it is essential to note that other metabolic products will be induced or secreted into the medium along with alkaline protease. Hence, the need to subject the produced alkaline protease to purification processes. The observed enzyme activity by Bacillus subtilis strain C3a-FIIRO shows its potential as a suitable hyper alkaline protease producer. Its high activity further reveals the need for purification to achieve enhanced stability and yield.

\section{Conclusion}

The combination of morphological, biochemical, and molecular tools was useful in identifying a novel alkaline protease producing bacterial strain as Bacillus subtilis C3a-FIIRO. The alkaline protease produced will be subjected to purification processes, kinetics, and thermodynamic characterization to ensure the purified enzyme has the properties suitable for industrial application.

\section{Acknowledgement}

All authors extend their gratitude to the Federal Institute of Industrial Research, Oshodi, Lagos for their support.

\section{References}

Aruwa, C. E. and Olatope S.O.A. (2015). Characterization of Bacillus Species from convenience foods with conventional and API kit method (2015): A comparative analysis. J. Appl. Life Sci. Int. 3(1): 42-48.

Bajpai, T., Varma. M., Bhatambare, G. and Pandey, M. (2017). Accurate identification of urinary isolates: Integration of conventional, automated, and molecular methods. Int. J. Health Allied Sci. 6(2): 82-87.

Balan, S.S., Nethaji, R., Sankar, S. and Jayalakshmi, S. (2012). Production of gelatinase enzyme from Bacillus spp isolated from the sediment sample of Port Novo coastal sites. Asian Pac. J. Tropic. Biomed. 1811-1816.

Bhosale, S. and Vijayalakshmi, D. (2015). Processing and nutritional composition of rice bran. Curr. Res. Nutr. Food Sci. 3(1): 74-80.

Caruso, G., Caruso, R. and Maimone, G. (2019). Microbial enzymatic activity measurement by fluorogenic substrates: Evidence of inducible enzymes in oligotrophic Mediterranean areas. J. Clin. Microbiol. Biochem. Technol. 5(2): 019024.

Cheng, S.W., Wang, Y.F. and Wang, M.L. (2012). Statistical optimization of medium compositions for alkaline protease production by newly isolated Bacillus amyloliquefaciens. Chem. Biochem. Eng. Quart. 26(3): 225-231.

Claus, D. and Berkeley R.C.W. (1986). Genus Bacillus: In: Bergey's manual of systematic bacteriology, Sneath, P.H.A., Mair, N.S. Sharpe, M.E. and Holt, J.G. (Eds). Williams and Wilkins Co, Balltimore., Pp. 1105-1139.

Dalvi P. and Anthappan P. (2007). Amylase and pectinase from single source for simultaneous 
desizing and scouring. Indian J. Fiber Text. Res. 32: $459-465$.

Demeli, M., Demirbag, Z. and Sezen, K. (2014). Isolation and Characterization of Bacillus from Some Warehouses in Trabzon. J. Appl. Biol. Sci. 8(2): 69-80.

Ellaiah P., Srinivasulu B. and Adrinarayana K. (2002). A review on microbial protease. J. Sci. Ind. Res. 61, 690-704.

Faria, A.S.C., Bassinello, P.Z. and Penteado, M.V.C. (2012). Nutritional composition of rice bran submitted to different stabilization procedures. Braz. J. Pharm. Sci. 48(4): 651-657.

Frederick, A., Huda, N. and Ali, G.R.R. (2013). Molecular techniques for detecting and typing of bacteria, advantages and application to foodborne pathogens isolated from ducks. Biotech. 3(2): 97-107.

Gordon, R.E, Haynes, W.C Pang, C.H.N. (1973). The Genus Bacillus: Agriculture Handbook No.427. Washington DC. United States Department of Agriculture, Pp.1-3.

Gouda, M.K. (2006). Optimization and purification of alkaline proteases produced by marine Bacillus $s p$. MIG newly isolated from eastern harbor of Alexandria. Pol. J. Microbiol. 55: 119-126.

Goto. K., Omura, T., Hara, Y. and Sadaie, Y. (2000). Application of the partial 16S rDNA sequence as an index for rapid identification of species in the genus Bacillus. J. Gen. Appl. Microbiol. 46(1): 1-8.

Gupta, R., Beg, Q.K. and Lorenz, P. (2002). Bacterial alkaline proteases: molecular approaches and industrial applications. Appl. Microbiol. Biotechnol. 59: 15-32.

Hussain, T., Roohi, A., Munir, S., Ahmed, I., Khan, J. Edel-Hermann, V., Kim, K.Y. and Anees, M. (2013). Biochemical characterization and identification of bacterial strains isolated from drinking water sources of Kohat, Pakistan. Afr. J. Microbiol. Res., 7(16): 1579-1590.
Imen, G., Anissa, H., Romdhane, M.B. and Ellouz-Chaanouni, S. (2016). Screening and molecular identification of new microbial strains for production of enzymes of biotechnological interest. Braz. Arch. Biol. Technol. 59: 1-12.

Imtiaz, S., Mukhtar, H. and Ikram-ul, H. (2013). Production of alkaline protease by Bacillus subtilis using solid state. Academic journal. 7(16): 1558-1568.

Johnson, Y.A., Nagpal, M., Krahmer, M.T., Fox, K.F. and Fox, A. (2000). Precise molecular weight determination of PCR products of the rRNA intergenic spacer region using electrospray quadrupole mass spectrometry for differentiation of B. subtilis and B. atrophaeus, closely related species of bacilli. J. Microbiol. Meth. 40: 241-254.

Karray, A., Alonazi, M., Horchani, H. and Bacha, A.B. (2021). A novel thermostable and alkaline protease produced from Bacillus stearothermophilus isolated from olive oil mill sols suitable to industrial biotechnology. Molecules. 26(1139): 1-15.

Kanghae, A., Monkai, J., Eungwanichayapant, P.D., Niamsup, P. and Chukeatirote E. (2016). Characterization of Bacillus species exhibiting strong proteolytic activity isolated from thua nao. Acta Alimentaria. 45(1): 11-19.

Keramas, G., Bang, D.D., Lund, M., Madsen, M., Bunkenborg, H., Telleman, P., Christensen, C.B.V. (2004). Use of culture, PCR analysis and DNA microarrays for detection of Campylobacter jejuni and Campylobacter coli from chicken faeces. J. Clin. Microbiol. 47: 3985-3991.

Khan, M.A., Ahmad, N., Zafar, A.U., Nasir, I.A. and Qadir, M.A. (2011). Isolation and screening of alkaline protease producing bacteria and physio-chemical characterization of the enzyme. African Journal of Biotechnology. 10(33): 62036212.

Kumar, C.G., Tiwari, M. P. and Jany, K. D. (1999). Novel alkaline serine protease from alkalophilic Bacillus Spp: Purification and some properties. Process Biochem. 34(5): 441-449. 
Khusro, A. and Aarti, C. (2015). Molecular identification of newly isolated bacillus strains from poultry farm and optimization of process parameters for enhanced production of extracellular amylase using ofat method. Res. J. Microbiol. 10: 393-420.

Lawal, A. k., Itoandon, E.E., Fashola, F.A., Ajayi, O., Ojo, E.E., Adepoju, F.A., Ugbana, A., Elemo, G. N. and Dike, E. N. (2014). Production of alkaline protease by Bacillus polymyxa using agro industrial waste by solid state fermentation. Global Advanced Research Journal of Microbiology. 3(3): $041-048$.

Logan, N.A. and Berkeley, R.C. (1984) Identification of Bacillus strains using the API system. J. Gen. Microbiol. 130(7): 1871-1882.

Magistrado, P., Carcia, M. and Raymundo, A. (2001). Isolation and polymerase chain reactionbase detection of Campylobacter jejuni and Campylobacter coli from poultry in Philippines. Int. J. Food Microbiol. 70(1-2): 197-206.

Manavalan, T., Manavalan, A., Ramachandran, S. and Heese, K. (2020). Identification of a novel thermostable alkaline protease from Bacillus megaterium-TK1 for the Detergent and Leather Industry. Biol. 9(472): 1-14.

Oxenbøll, K. and Ernst, S. (2008). Environment as a new perspective on the use of enzymes in the food industry. Food Sci. Technol. 22(1): 3537.

Pandey, A., Nigam, P., Soccol, C.R., Soccol, V.T., Singh, D., and Mohan, R. (2000). Advances in microbial amylases. Biotechnol. Appl. Biochem. 31: $135-152$.

Paucar-Menacho, L.M., Silva, L.H. Santana, A.S. \& Goncalve, L.A.G. (2007). Refining of rice bran oil (Oryza sativa L.) to preserve y-orizanol. Ciênc. Tecnol. Aliment.

27(1): 45-53.

Razzaq, A., Shamsi, S., Ali, A., Ali, Q., Sajjad, M., Malik, A. and Ashraf, M. (2019). Microbial proteases applications. Front. Bioeng. Biotechnol. 71(110): 1-20.
Sayaniya, A.V. and Patel, P. (2021). Isolation and characterization of detergent compatible alkaline protease producing Bacillus subtilis APO-1. Biomed. J. Sci. Tech. Res. 35(5): 2794927955.

Shafee, N., Aris, S. N., Zaliha, R.N., Rahman, A.B.S., Basri, M., Salleh, A.B. and Aris, S.N.A.M. (2005). Optimization of environmental and nutritional conditions for the production of alkaline protease by a newly isolated bacterium Bacillus cereus strain 146. J. Appl. Sci. Res.1(1):1-8.

Sharif, A., Nasreen, Z. and Kalsoom, S. (2020). Isolation, screening, characterization of proteolytic bacteria and production of protease with its potential applications. Pure Appl. Biol. 9(4): 2250-2271.

Sharma, M., Gat, Y., Arya, S., Kumar, V., Panghal, A. and Kumar A. (2019). A Review on Microbial Alkaline Protease: An Essential Tool for Various Industrial Approaches. Ind. Biotechnol. 15(2): 69-78.

Shumi, W., Hossain, M.T. and Anwar, M.N. (2004). Proteolytic activity of a bacterial isolate Bacillus fastidiosus den Dooren de Jong. J. Biol. Sci. 4(3): 370-374.

Singh, J., Vohra, R.M., Sahoo, D.K. (1999). Alkaline protease from a new obligate alkalophilic isolate of Bacillus sphaericus. Biotech. Lett. 21: 921-924.

Sreedevi, S. and Reddy, B. (2012). Isolation, screening and optimization of phytase production from newly isolated Bacillus sp. C 43. Int. J. Pharm. Biol. Sci. 2: 218-231.

Thompson, J.M., Dodd, C.E.R. and Waites, W.M. (1993). Spoilage of bread by Bacillus. Int. Biodeterior. Biodegradation. 32: 55-66.

Varia, A.D., Shukla, V.Y. and Tipre, D.R. (2019). -Alkaline protease enzyme: A versatile enzyme. Int. J. Res. Anal. Rev. 6(2): 208-217.

Vijayalakshmi, K., Sushma, S., Abha and Chander P. (2012). Isolation and characterization of Bacillus subtilis KC3 for amylolytic activity. Int. J. Biosci. Biochem. Bioinform. 2(5): 336-341. 
Fashola et al. / Nig. J. Biotech. Vol. 38 Num. 2 : 56-66 (December 2021)

Zhou, C., Zhou, H., Zhang, H. and Lu, F. (2019). Optimization of alkaline protease production by rational deletion of sporulation related genes in Bacillus licheniformis. Microbl. Cell Fact. 18(127): 1-12.

Kim, Y-K., Lee, S-C., Cho, Y-Y., Oh, H.J. and Ko, Y.H. (2012). Isolation of Cellulolytic Bacillus subtilis Strains from Agricultural Environments. Int. Sch. Res. Net. Microbiol. 2012: 1-9. 